\title{
CTPERUS ERAGROSTIS LAM. - A NEW ADVENTITIOUS SPECIES IN THE FLORA OF SLOVENIA
}

\author{
Igor DAKSKOBLER ${ }^{1} \&$ Branko VRES̆ $^{2}$
}

\begin{abstract}
About ten years ago Cyperus eragrostis, a species originating in the tropical parts of South America, settled in a trench near the house at Podsabotin 49 in the Goriška Brda. From there the plant spread to similar neighbouring ruderal sites with hydromorphic soil, to roadside ditches and gravelly banks of the Pevmica, a stream on the border between Slovenia and Italy. Applying the standard Central-European phytosociological method we studied the stands in which this species grows together with other hygrophilous and ruderal species. These stands are dominated by character species of the classes Bidentetea tripartitae, Filipendulo-Convolvuletea, Molinio-Arrhenatheretea, Stellarietea mediae and Galio-Urticetea. Cyperus eragrostis is a new adventitious species in the Slovenian flora. Its ephemeral occurrence in Slovenia was first noted in Istria in 2003 (near Portorož, probably in the Sečovlje salt-pans) and later in 2006 (Gračišče). Its presence in Podsabotin and along the Pevmica, however, is not merely transitional (ephemeral); here, this alien species is likely to have already naturalized in the environment with warm and relatively moist sub-Mediterranean climate.
\end{abstract}

Key words: Cyperus eragrostis, Bidentetea tripartitae, Filipendulo-Convolvuletea, Potentillo-Polygonetalia, Podsabotin, the Goriška Brda (Collio), the Pevmica (Piumizza), Slovenia, Italy.

\section{Izvleček}

Cyperus eragrostis, vrsta, ki je doma v tropskih predelih Južne Amerike, se je pred približno desetimi leti naselila v izkop pri hiši Podsabotin 49 v Goriških Brdih. Od tam se je razširila na podobna okoliška ruderalna rastišča s hidromorfnimi tlemi, v obcestne jarke in na prodnate bregove Pevmice, ki je mejni potok med Slovenijo in Italijo. Po standardni srednjeevropski fitocenološki metodi smo preučili sestoje, v katerih uspeva skupaj z drugimi vlagoljubnimi in ruderalnimi vrstami. V njih prevladujejo značilnice razredov Bidentetea tripartitae, Filipendulo-Convolvuletea, Molinio-Arrhenatheretea, Stellarietea mediae in Galio-Urticetea. Cyperus eragrostis je nova adventivna vrsta v flori Slovenije. Prvič je bilo v Sloveniji zabeleženo njeno efemerno pojavljanje v Istri leta 2003 (pri Portorožu, verjetno v Sečoveljskih solinah) in kasneje še leta 2006 (Gračišče). Njena prisotnost v Podsabotinu in ob Pevmici ni zgolj prehodna (efemerna), temveč se je v okolju s toplim in razmeroma vlažnim submediteranskim podnebjem ta tujerodna vrsta že udomačila (naturalizirala).

Ključne besede: Cyperus eragrostis, Bidentetea tripartitae, Filipendulo-Convolvuletea, Potentillo-Polygonetalia, Podsabotin, Goriška Brda (Collio), Pevmica (Piumizza), Slovenija, Italija.

\section{INTRODUCTION}

In the Slovenian flora genus Cyperus is represented with eight species (Martinčič 2007: 802-803). Seven of those species (Cyperus longus, C. glomera- tus, C. glaber, C.fuscus, C. michelianus, C serotinus and $C$. flavescens) are autochtonous, while Cyperus esculentus was imported or is a remains of former cultivation. Its homeland is the Mediterranean (Martinčič 2007). This paper will present a new

\footnotetext{
${ }^{1}$ Institute of Biology, Scientific Research Centre of the Slovenian Academy of Sciences and Arts, Regional unit Tolmin, Brunov drevored 13, SI-5220 Tolmin, Igor.Dakskobler@guest.arnes.si

${ }^{2}$ Institute of Biology, Scientific Research Centre of the Slovenian Academy of Sciences and Arts, Novi trg 2, SI-1000 Ljubljana, braneVr@zrc-sazu.si
} 
adventitious species to the flora of the Soča Valley, Cyperus eragrostis, together with its localities and sites along the Pevmica in the Goriška Brda (in Slovenia and Italy) - between Podsabotin and Pevma (Piuma).

Cyperus eragrostis is an autochtonous species of tropical regions of South America. From there it spread, mostly with exotic oil seed crops and wool, into southwest Europe (Spain, France), California, New Zealand and elsewhere. So far it has been noticed in many European countries (Italy, Germany, Austria, Switzerland, the Netherlands, Belgium, Hungary, Croatia) - DeFilipps 1980, Schultze-Motel 1980, Poldini et al. 2001, Starmühler 2005, 2006, 2008). In the hilly regions under the Alps it most commonly grows in therophyte pioneer communities on nutritious soil (alliance Bidention tripartitae) - Aeschimann et al. (2004 b: 774). The species was noticed the closest to the new locality in 1997 in the basic field 10346 of the Central-European mapping grid in Friuli Venezia Giulia (Poldini et al. 2001: 103). In Slovenia it was first collected by K.-G. Bernhardt in the autumn of 2003 on wet ruderal spots in "Salinen von Portoroz" (in the salt-pans of Portorož), probably in the Sečovlje salt-pans - Starmühler (2006: 548) and later (in 2006) in Gračišče (Starmühler 2008: 593). K.-G. Bernhardt found the plant also near Motovun in the Mirna valley in Istria, also in 2003, which was its first find in Croatia (Starmühler 2005: 625). So far, it has not been included into the Slovenian flora (Martinčič 2007).

\section{METHODS}

The flora and vegetation were recorded applying the established Central-European methods (Ehrendorfer \& Hamann 1965, Braun-Blanquet 1964) and the Europaean Flora mapping method (Jalas \& Suominen 1967). Field data (floristic and phytocoenological relevés) were entered into the FloVegSi database (Fauna, Flora and Vegetation of Slovenia) of the Jovan Hadži Institute of Biology at the SRC SASA (Seliškar \& al. 2003), which was used also in the preparation of maps. The relevés were arranged into a phytocoenological table by means of hierarchical classification. Programme package SYN-TAX (Podani 2001) was used. The nomenclature source for the names of vascular plants is the Mala flora Slovenije (Martinčič \& al. 2007). For descriptions of lo- calities we used basic topographical maps of RS $1: 5000$, the state topographical map of RS in the scale of 1: 25000 (GURS) and Atlas of Slovenia in the scale of $1: 50000$ ( $3^{\text {rd }}$ edition 1996). The description of Cyperus eragrostis and its general distribution have been summarized according to the following works: Flora Europaea (DeFilipps 1980: 286), Illustrierte Flora von Mitteleuropa (Schultze-Motel 1980), Flora d'Italia (Pignatti 1982: 696), Flora alpina (Aeschimann et al. 2004 b: 774), Flora Helvetica (Lauber \& Wagner 1998: 1266) and Exkursionsflora von Österreich, Liechtenstein und Südtirol (Fischer et al. 2008: $1108)$; it is supplemented with our own measurements on the herbarized material which is kept in the working herbarium of the Jovan Hadži Institute of Biology at the SRC SASA. Sources for the syntaxonomical nomenclature and for the ecological and phytosociological characterisation of plant species in our relevés (Table 1) are Mucina et al. (1993) and Aeschimann \& al. (2004 a, b, c).

\section{RESULTS}

\subsection{Genus Cyperus in the Soča Valley}

The following taxa from the genus Cyperus have been recorded while mapping the flora of the Soča Valley: Cyperus fuscus, Cyperus flavescens and Cyperus esculentus (the latter also near Tolmin, $9848 / 1$, on a backfill on the right bank of the Soča upstream from the separation of Cestno podjetje Nova Gorica - Road Company Nova Gorica, leg. \& det. I. Dakskobler, 30. 8. 2008, working herbarium ZRC SAZU). Their distribution in this part of Slovenia is presented in Figures 1 and 2. When recording the flora and vegetation of the Goriška Brda we found another galingale, Cyperus eragrostis, in the autumn of 2008 (Figure 3 ). This, however, is not an autochtonous species of Slovenian flora, but a neophyte, an immigrant from the tropical regions of South America.

\subsection{Description of CYPERUS ERAGRostis}

Cyperus eragrostis Lam. (C. vegetus Willd.) - Pale Galingale, is a shortly rhizomatous perennial herb (geophyte). The culms are trigonous to terete, glabrous, (10-) 25 to $90(-100) \mathrm{cm}$ long with solitary leaves at the base. The leaves are flat or V-shaped, solitary, (3-) 4 to $8(-10) \mathrm{mm}$ wide, shorter than 


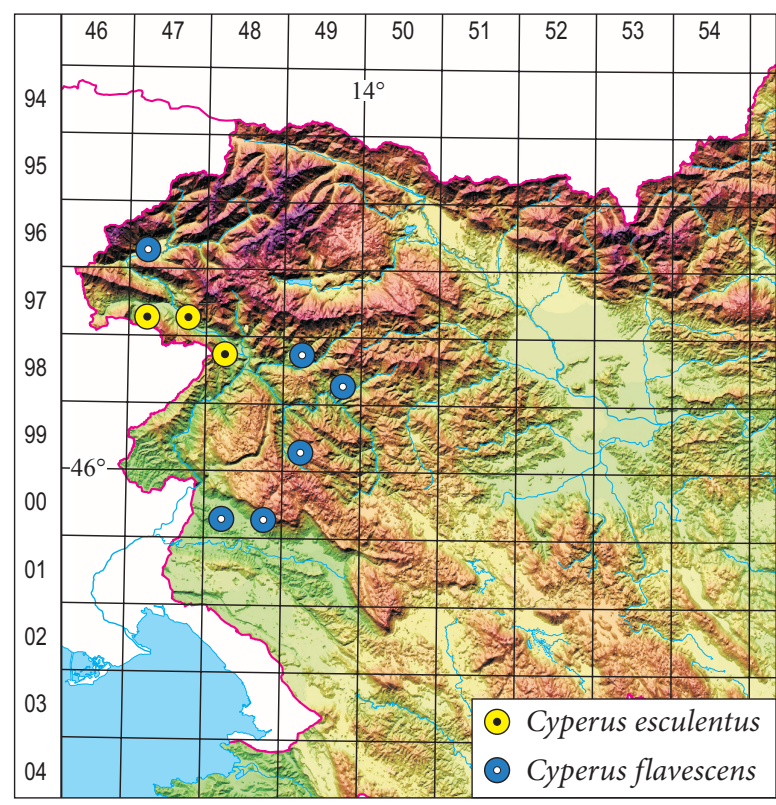

Figure 1: Distribution of Cyperus esculentus and C. flavescens in the Soča Valley.

Slika 1: Razširjenost vrste Cyperus esculentus in C. flavescens.

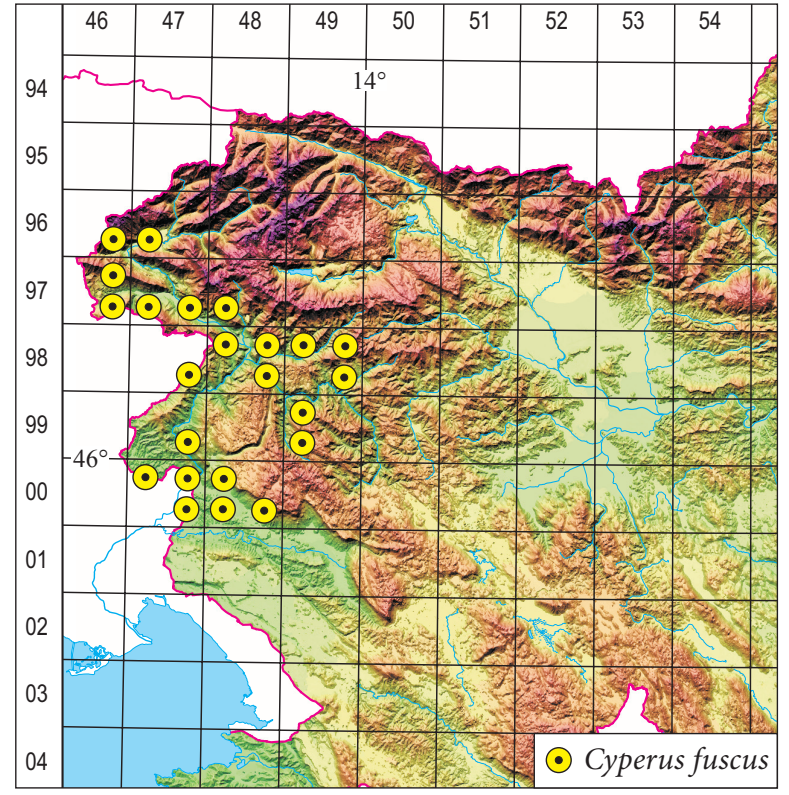

Figure 2: Distribution of Cyperus fuscus in the Soča Valley. Slika 2: Razširjenost vrste Cyperus fuscus v Posočju.

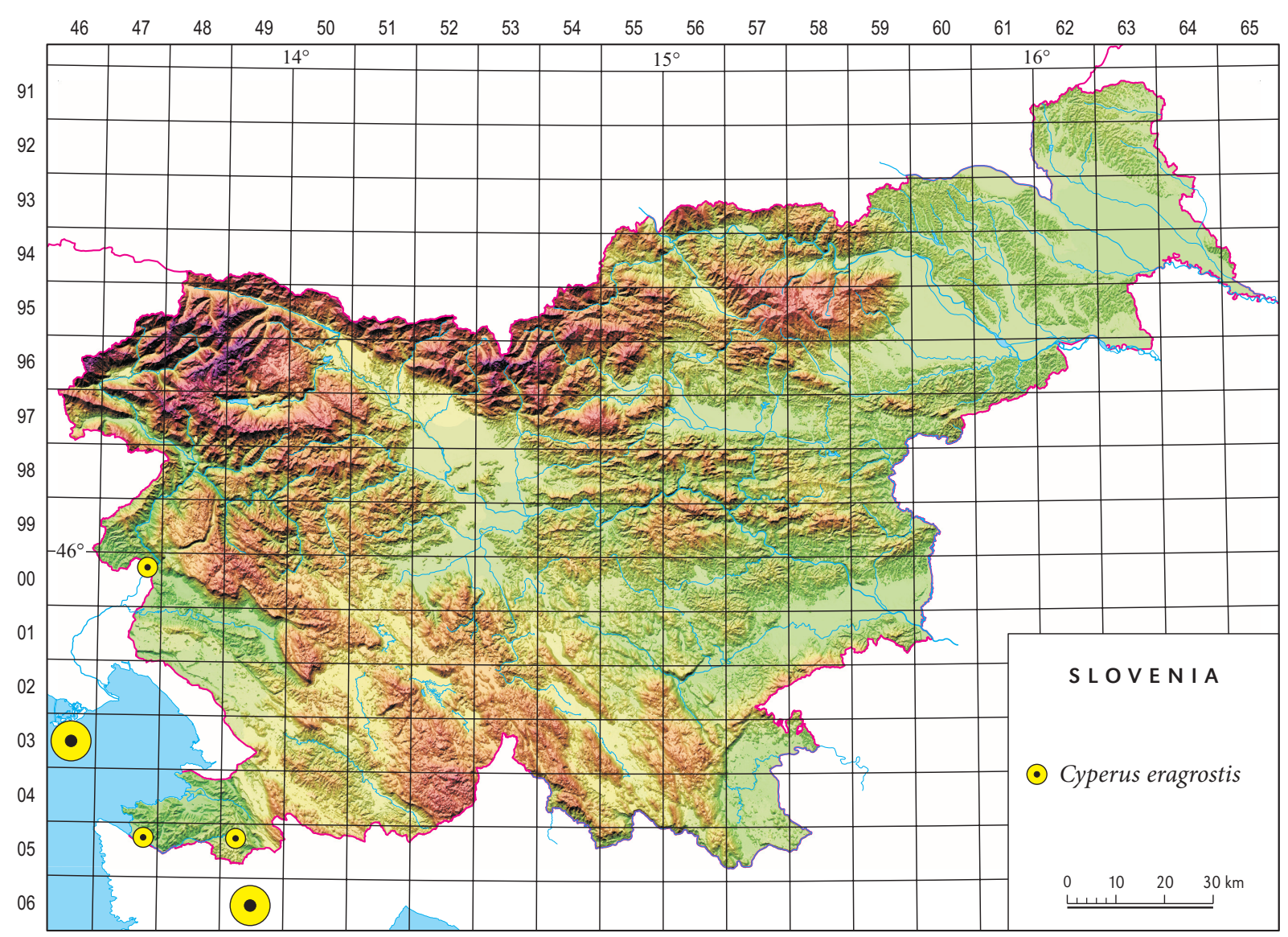

Figure 3: Distribution of Cyperus eragrostis in Slovenia and in neighbouring parts of Friuli Venezia Giulia (NE-Italy) and Croatia. Slika 3: Razširjenost vrste Cyperus eragrostis v Sloveniji in v sosednjih območjih Furlanije (severovzhodne Italije) in Hrvaške. 
or at the most as long as the culm. Bracts (4-) 5 to $8(-11)$, much exceeding the inflorescence. Inflorescence is a simple to compound umbel of globose heads (Figures 5 and 6), 10 to $20(-30)$ $\mathrm{mm}$ in diameter; inflorescence rays are (1-) 3 to $10(-12) \mathrm{cm}$ long. Spikelets are narrowly lanceolate, flat, (5-) 10 to 15 (-20) mm long, yellowishgreen to rusty brown, with (10-) 20 to $40(-45)$ flowers per spikelet; floral scales often drop off in the lower half of the spikelet when ripe. Stamen 1 , styles 3. Fruits (achenes) are trigonous, broadly ellipsoid, ca. half as long as the glumes (1.2-1.4 $\mathrm{mm}$ ), off-white (greyish) to golden brown.

\subsection{DESGRIPTION OF LOGALITIES AND SITES OF CYPERUS ERAGROSTIS IN THE GORIŠKA BRDA}

0047/2 (UTM 33T UL99): Slovenia, the Goriška Brda: a ditch alongside the road Podsabotin-Pevma (Piuma), by the house at Podsabotin 49, in ruderal communities (trench, roadside ditch, Table 1 , relevés 3,4 and 5) at about $90 \mathrm{~m}$ a. s. 1 ., and on the left bank of the Pevmica, $85 \mathrm{~m}$ a. s. 1 . (Table 1, relevé 1). Leg. \& det. I. Dakskobler, 3.
9. 2008 and I. Dakskobler \& B. Vreš, 16. 9. 2008, working herbarium ZRC SAZU (SRC SASA).

0047/2 (UTM 33T UL99): Italia, Friuli, Brda (Collio): on the right and the left bank of the Pevmica (Piumizza), under Oslavje (Oslavia) at about $90 \mathrm{~m}$ a. s. l., in ruderal communities on gravel along the stream (Table 1, relevé 2). Leg. \& det. I. Dakskobler \& B. Vreš, 16. 9. 2008, working herbarium ZRC SAZU (SRC SASA). The second locality in Friuli Venezia Giulia (compare Poldini et al. 2001: 103).

Cyperus eragrostis was located near Podsabotin in the Goriška Brda (Figure 4). This hilly flysch landscape has a sub-Mediterranean hinterland climate (Ogrin 1996). The climatic conditions can be described with the data for the measuring station Vipolže (98 $\mathrm{m}$ a. s. 1.). The average annual temperature here in the period 1961-1990 was $12.4^{\circ} \mathrm{C}$ (interpolated value), the average temperature of the warmest month, July, was $21.9^{\circ} \mathrm{C}$ and the average temperature of the coldest month, January, was $3.3^{\circ} \mathrm{C}$. The vegetation period with the average daily temperature above $10^{\circ} \mathrm{C}$ lasted from April to October and with the average daily

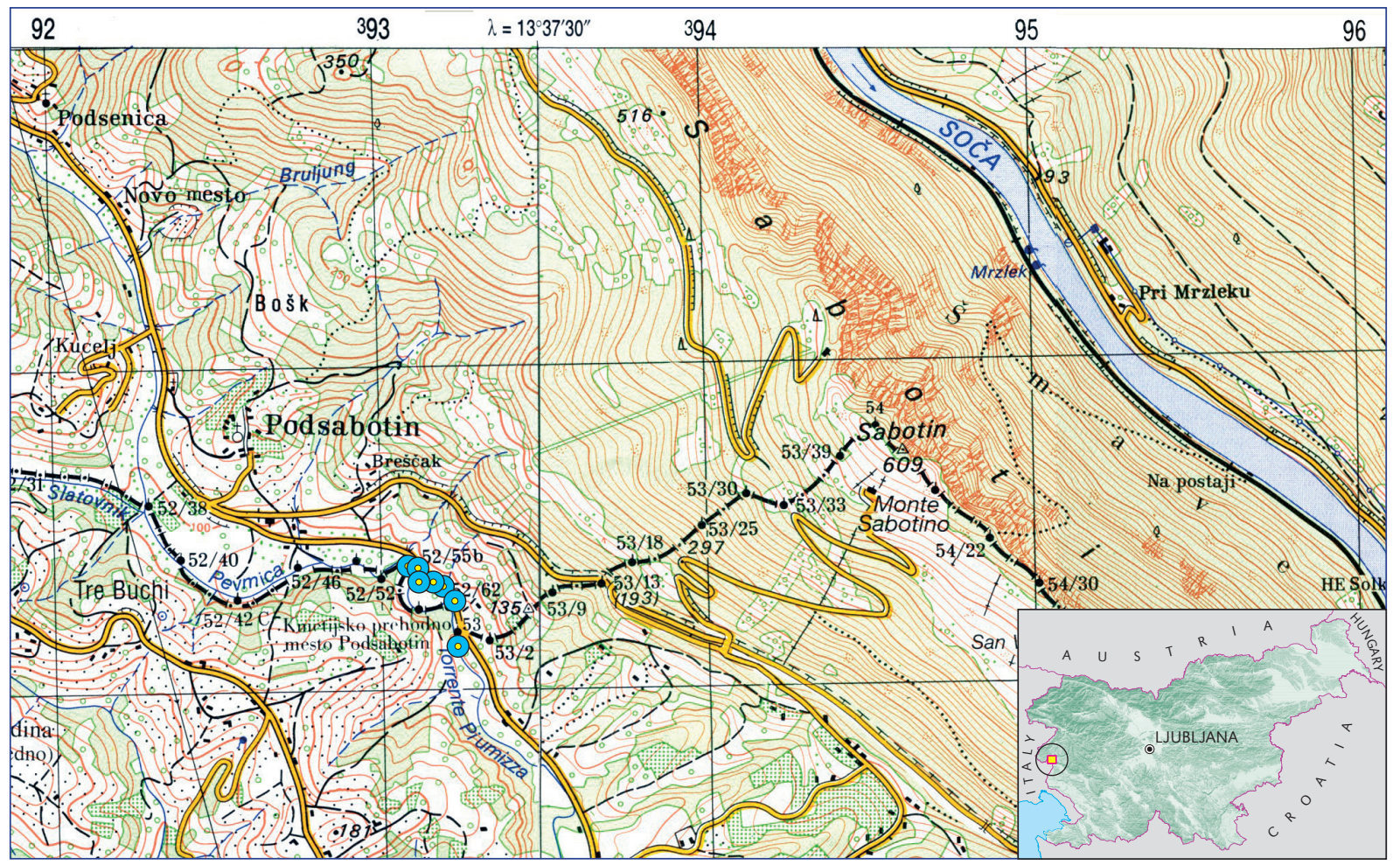

Figure 4: Localities of Cyperus eragrostis at Podsabotin (Source: State topographical map 1: 25000, GURS).

Slika 4: Nahajališča vrste Cyperus eragrostis pri Podsabotinu (Vir: Državna topografska karta 1: 25000, GURS). 

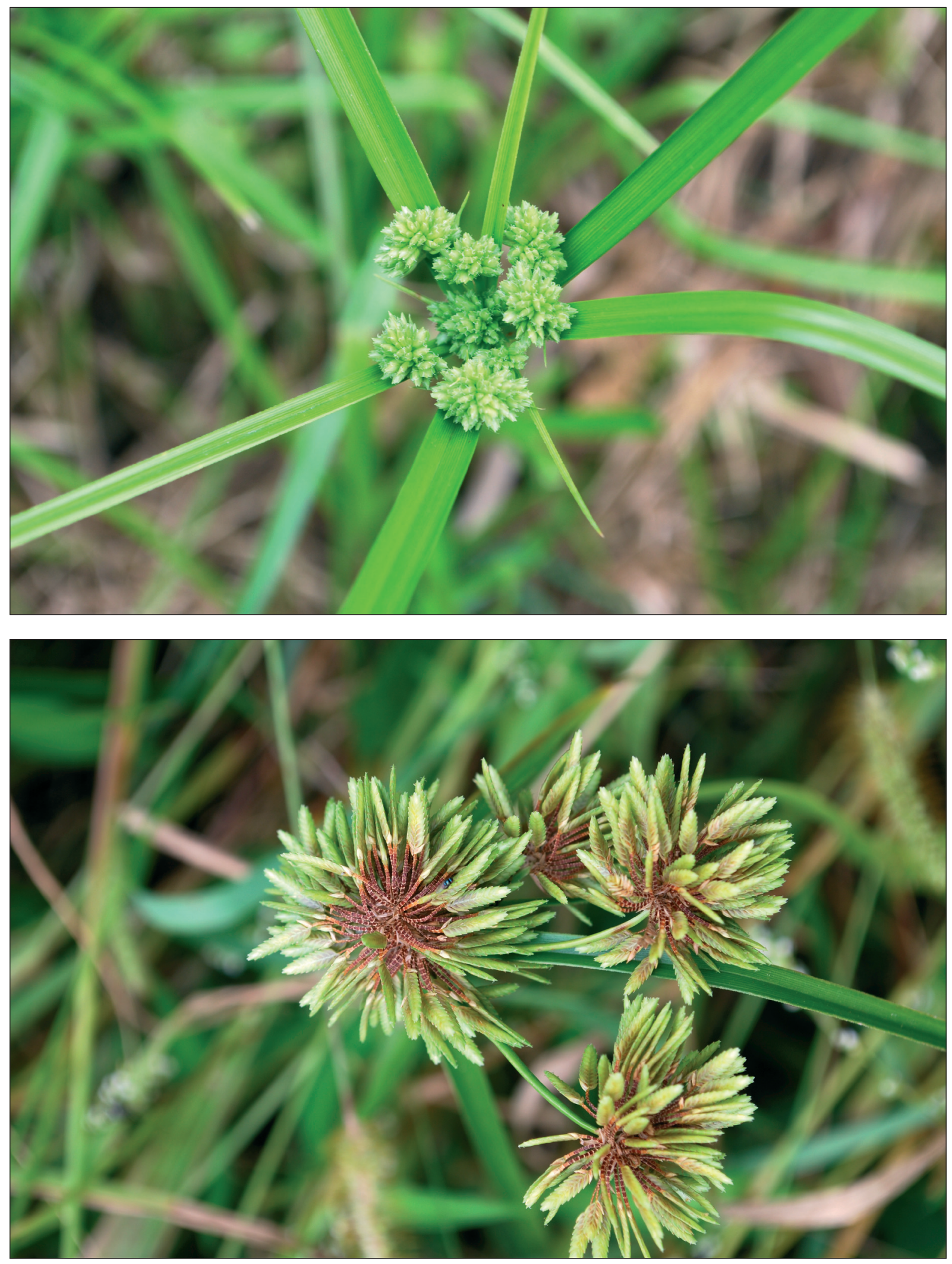

Figure 5 and 6: Cyperus eragrostis - inflorescence. (Photo Branko Vreš) Sliki 5 in 6: Cyperus eragrostis - socvetje. (Foto Branko Vreš) 
temperature above $5{ }^{\circ} \mathrm{C}$ from March to November (Mekinda-Majaron 1995: 128). In the same period (1961-1990) the average annual precipitation in Vipolže amounted to $1540 \mathrm{~mm}$ (interpolated value). The precipitation is evenly distributed throughout the year (on average the least precipitation occurs in February and the most in October, but during the vegetation period between April and November there was $948 \mathrm{~mm}$ of precipitation, which is over $60 \%$ of total value) - Zupančič (1995: 334).

Lidija Škaper (Podsabotin 49) has been aware of the Pale Galingale (Cyperus eragrostis) in the vicinity of her homestead for over 10 years. At that time a trench had been made behind the house and among other species this one also populated the new site. In the following years it spread to similar ruderal sites in the vicinity, into roadside ditches (Figure 7) and on the gravel along the Pevmica (Figures 8-10). Its communities are presented in Table 1.

At Podsabotin Cypeus eragrostis grows mostly on hydromorphic soil. This soil is permanently to temporarily wet due to the ground, surface and/or flood waters (Urbančič et al. 2005: 5). In some places on the studied sites the soil is deep, anthropogenous (the trench along the house), in some places shallow (the roadside ditch) or undeveloped (fluvisol on the gravel along the stream). The sites along the stream are periodically flooded, but they can also be dried out during the dry season. The stand on relevé 5 in Table 1 is somewhat similar to the communities from the alliance Bidentition tripartitae, while the stand in relevé 1 resembles the communities from the order Potentillo-Polygonetalia (e.g. the stands of the association Rumici crispi-Agrostietum stoloniferae). The stands from relevés 2, 3 and 4 are transitional between the stands in relevés 1 and 5 . They differ from them mostly because of the higher proportion of weeds from the class Stellarietea mediae. For now Cyperus eragrostis in the Soča Valley thrives in a warm and relatively moist sub-Mediterranean climate on hydromorphic soil, in ruderal communities in roadside ditches, trenches and on flysch gravel along streams. In initial communities on such sites it grows together mostly with the species characteristic for syntaxa from the classes Bidentetea tripar-

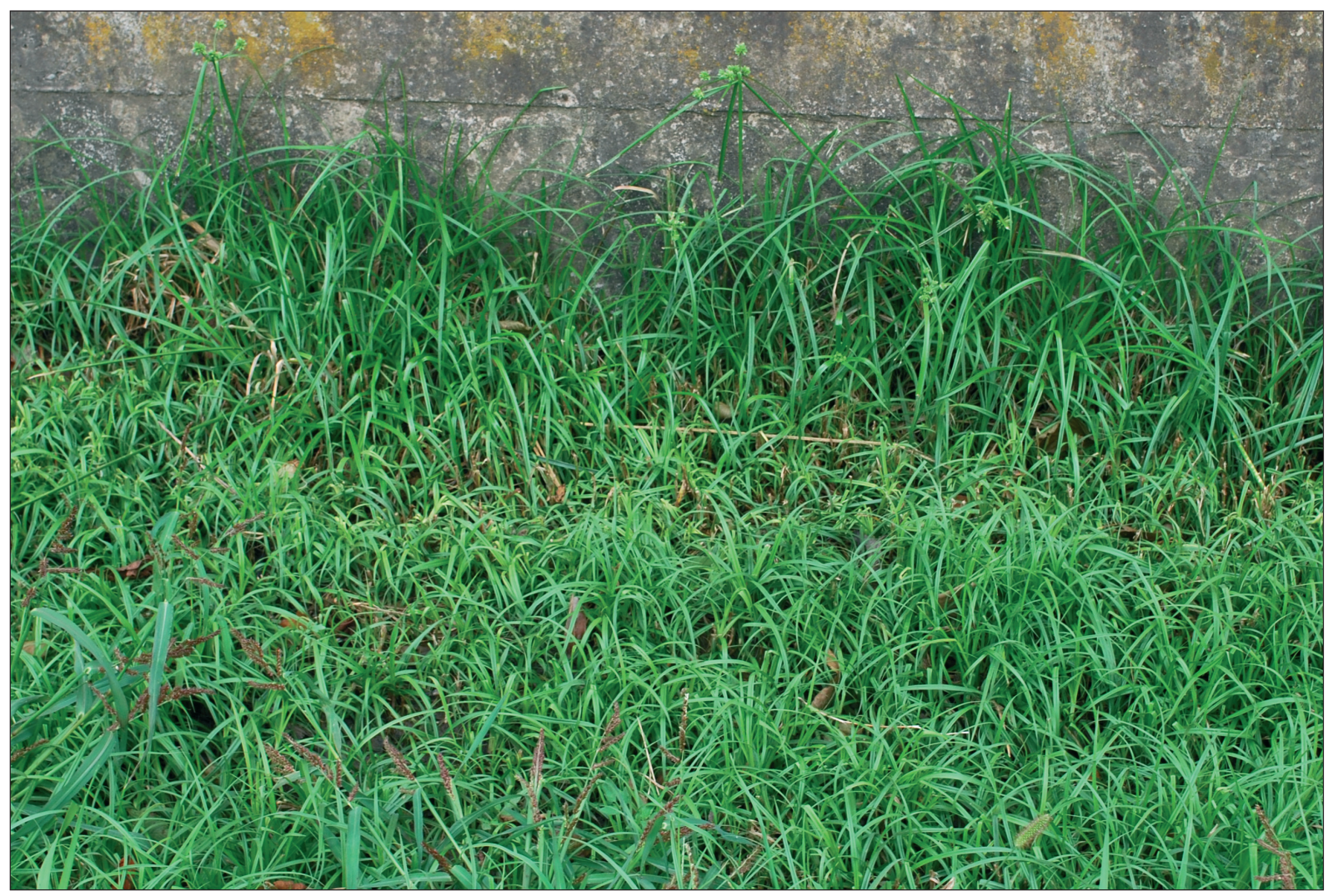

Figure 7: Stand with Cyperus eragrostis in Podsabotin, roadside ditch, relevé 4 in Table 1. (Photo Branko Vreš) Slika 7: Sestoj z vrsto Cyperus eragrostis v Podsabotinu, obcestni jarek, popis $4 \mathrm{v}$ tabeli 1. (Foto Branko Vreš) 

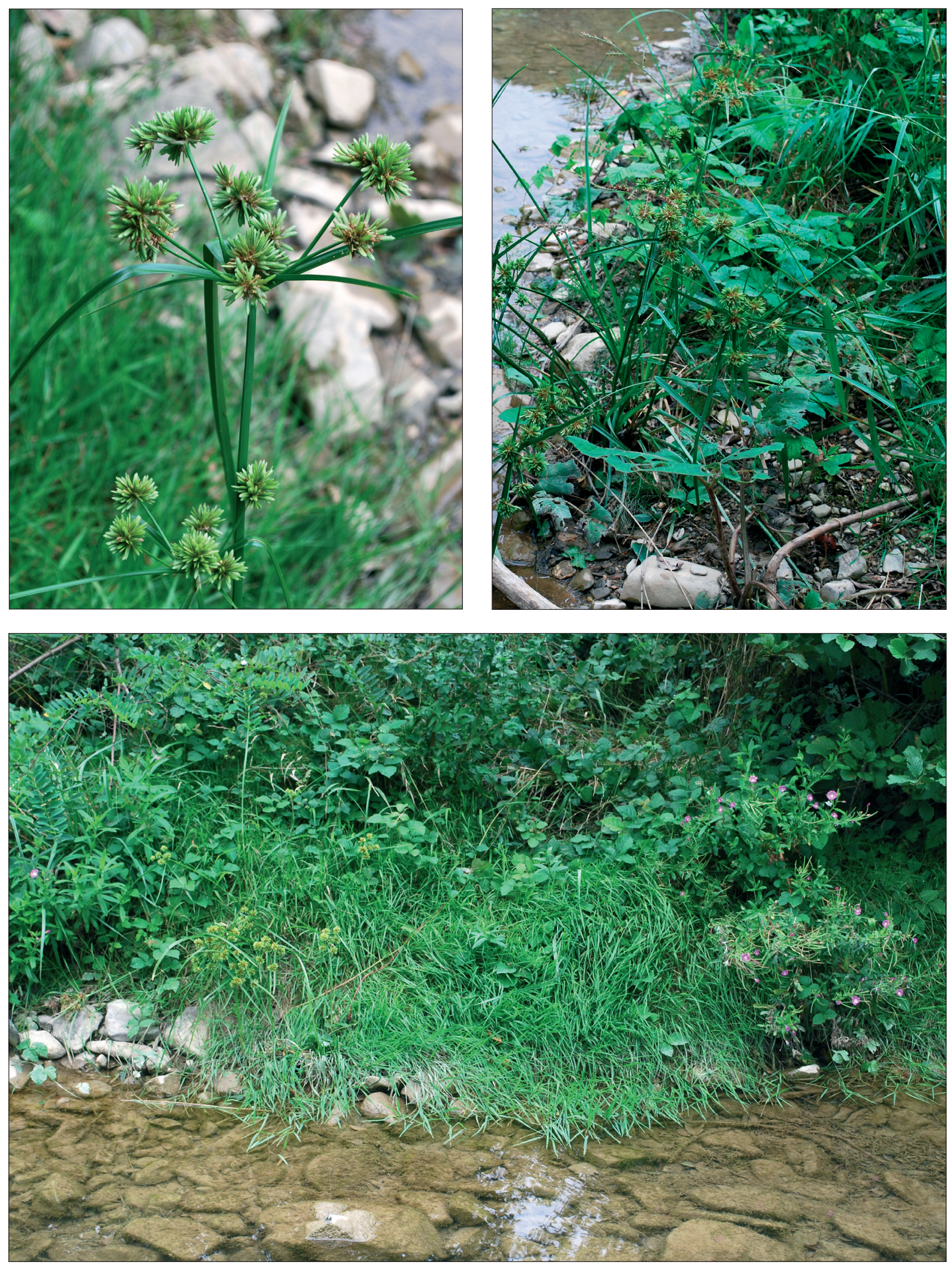

Figures 8-10: Cyperus eragrostis on the banks of the Pevmica (Piumizza) at Podsabotin (Slovenia and Italy). (Photo B. Vreš) Slike 8-10: Cyperus eragrostis na bregovih Pevmice pri Podsabotinu (Slovenija in Italija). (Foto Branko Vreš) 
titae, Filipendulo-Convolvuletea, Molinio-Arrhenatheretea (above all from the order Potentillo-Polygonetalia), Stellarietea mediae and Galio-Urticetea. As it has been occurring in Podsabotin for a long while (at least 10 years) and is also spreading to new sites (along Pevmica river), we can conclude that its occurrence is no longer merely transitional (ephemeral); in the warm and relatively moist sub-Mediterranean climate of the flysch hills in the foothills of the Julian Alps the species has actually already naturalised (according to the recommended terminology in Richardson 2000).

Due to the lack and even absence of investigations on the species' distribution potential in Slovenia it cannot be positively categorised as an invasive species. It could, however, be potentially invasive.

\section{CONCLUSIONS}

Occurrence of Cyperus eragrostis in the Friuli (NEItaly) was treated as transitional and was therefore not included into the Atlas (Poldini 2002). In the lower Goriška Brda, in the border region along the Pevmica near Podsabotin (0047/1, UTM 33T UL99, in both Slovenian and Italian territories), this galingale has been observed for over 10 years (Lidija Škaper, oral notice of 16. 9. 2008). It has populated the trench behind the house at Podsabotin 49 and spread from there to similar ruderal sites (a roadside ditch, gravelly banks of the Pevmica), where it grows on hydromorphic soil together with other hygrophilous ruderal species characteristic for the classes Bidentetea tripartitae, Filipendulo-Convolvuletea, Molinio-Arrhenatheretea, Stellarietea mediae and Galio-Urticetea. As it has been occurring in Podsabotin for a long while and is also spreading to new sites, we can conclude that its occurrence is no longer merely transitional (ephemeral); in the warm and relatively moist sub-Mediterranean climate of the flysch hills the species has actually already naturalised.

\section{POVZETEK}

\section{Cyperus eragrostis Lam. - nova adventivna vrsta v flori Slovenije}

Rod Cyperus je v bil doslej v flori Slovenije zastopan z osmimi vrstami (Martinčič 2007: 802-803). Med njimi je sedem vrst (Cyperus longus, C. glo- meratus, C. glaber, C.fuscus, C. michelianus, C. serotinus in C. flavescens) avtohtonih, vrsta Cyperus esculentus pa zanesena oz. ostanek nekdanje gojitve. V Posočju smo poznali tri izmed naštetih vrst: Cyperus fuscus, Cyperus flavescens in Cyperus esculentus (sliki 1 in 3). Pri popisovanju flore in vegetacije v Goriških Brdih smo jeseni leta 2008 našli kosmatkasto ostrico, Cyperus eragrostis Lam. (C. vegetus Willd.) - slika 3, ki pa ni avtohtona vrsta naše flore, temveč neofit, priseljenka iz tropskih krajev v Južni Ameriki. To je zelnata trajnica (geofit) s kratko koreniko. Steblo je v spodnjem delu olistano s posamičnimi listi, topo trirobo, golo, dolgo (10) 25 do 90 (100) cm. Listi so (3) 4 do 8 (10) mm široki, sploščeni ali žlebasti, krajši ali največ tako dolgi kot steblo. Podpornih listov je (4) 5 do 8 (11), po dolžini močno presegajo razvejeno socvetje. To je (redko) enostavno ali običajno sestavljeno iz mnogih (1) 3 do 10 (12) $\mathrm{cm}$ dolgih vejic, ki imajo na vrhu kroglasto oblikovana delna socvetja s premerom 1 do $2(3) \mathrm{cm}$ (sliki 6 in 7). Klaski so ozko suličasti, sploščeni, dolgi (5) 10 do 15 (20) mm, rumenozeleni do rumenorjavi (rjasti), z (10) 20 do 40 (45) cvetovi; ob zorenju cvetovi v spodnji polovici klaska pogosto odpadejo. Cvet ima en prašnik in tri brazde. Plodovi (oreški) so trirobi, široko eliptični, bleščeče svetlo rjavi do sivkasti, polovico tako dolgi $(1,2-1,4 \mathrm{~mm})$ kot pleve.

Kosmatkasta ostrica se je predvsem z eksotičnimi oljnicami in volno razširila $\mathrm{v}$ jugozahodno Evropo (Španijo, Francijo), v Kalifornijo, na Novo Zelandijo in drugam. V Evropi se adventivno pojavlja še v nekaterih drugih državah (Italiji, Nemčiji, Avstriji, Švici, Nizozemski, Belgiji, Madžarski). Aeschimann et al. (2004: 774) so jo označili kot vrsto, ki v gričevjih pod Alpami največkrat uspeva $\mathrm{v}$ terofitskih pionirskih združbah na hranljivih tleh (zveza Bidention tripartitae). Najbližje novemu nahajališču so jo opazili leta $1997 \mathrm{v}$ Furlaniji Julijski krajini (Poldini et al. 2001: 103). V Sloveniji jo je prvič nabral K.-G. Bernhardt jeseni leta 2003 na mokrih ruderalnih rastiščih v solinah pri Portorožu (»Salinen von Portoroz«, najbrž so s tem izrazom mišljene Sečoveljske soline) - Starmühler (2006: 548), ter kasneje (leta 2006) še v Gračišču (Starmühler 2008: 593). K.-G. Bernhardt jo je našel tudi pri Motovunu v dolini reke Mirne v Istri, prav tako leta 2003, kar je bila prva najdba na Hrvaškem (Starmühler 2005: 625). V spodnjih Goriških Brdih, v obmejnem predelu ob Pevmici v Podsabotinu (0047/1, UTM 33T UL99 na slovenskem in italijanskem ozemlju - slika 4), 
to ostričevko domačini opažajo že več kot 10 let (Lidija Škaper, ustno sporočilo 16. 9. 2008). Naselila se je v izkop za hišo Podsabotin 49 in od tam na podobna ruderalna rastišča (obcestni jarek - slika 7, prodnati bregovi Pevmice - slike 8 do 10), kjer na hidromorfnih tleh raste skupaj z drugimi vlagoljubnimi ruderalnimi vrstami, značilnicami razredov Bidentetea tripartitae, FilipenduloConvolvuletea, Molinio-Arrhenatheretea, Stellarietea mediae in Galio-Urticetea. Po standardni srednjeevropski metodi smo popisali te sestoje (tabela 1) in ugotavljamo, da so nekateri od njih podobni združbama iz zveze Bidentition tripartitae, nekateri pa združbam iz reda Potentillo-Polygonetalia (npr. sestojem asociacije Rumici crispi-Agrostietum stoloniferae). Ker se kosmatkasta ostrica v Podsabotinu pojavlja že dlje časa in ker se širi na nova rastišča, sklepamo, da ne gre več le za prehodno (efemerno) pojavljanje, temveč da se je v toplem in razmeroma vlažnem submediteranskem podnebju flišnega gričevja v prigorju Julijskih Alp ta vrsta že naturalizirala (v smislu terminologije, ki jo priporoča Richardson (2000)). Zaradi pomanjkanja oz. doslej še neizvedenih raziskav njenih sposobnosti razširjanja v Sloveniji je ne moremo uvrstiti v kategorijo invazivnih vrst, lahko pa je potencialno invazivna.

Določevalni ključ (dopolnilo ključu v Martinčič et al. 2007):

\section{Cyperus L. - ostrica}

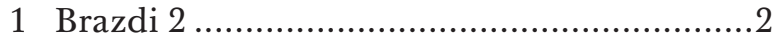

- Brazde 3.....................................................

4 Socvetje \pm glavičasto, zgoščeno …................ 5

- Socvetje ni glavičasto, rahlo .........................7

5 Trajnice, $\mathrm{z}$ rizomom ali živicami, s posamičnimi ali šopasto zgoščenimi stebli..................5a

- Enoletnice, brez rizoma ali živic, s šopasto

zgoščenimi stebli ...........................................6

5a Rastline navadno s posamičnimi stebli. Živice večinoma manjkajo. Klaski zgoščeni v klobčastih - glavičastih (pri mladih rastlinah) ali jajčastih do valjasto podaljšanih - delnih socvetjih. Krovne pleve ozko suličaste do črtalaste, bledo- do rdečkastorjave. Plodovi 3- do 4-krat daljši kot široki; prašniki 3 3. C. glomeratus

- Rastline s posamičnimi ali šopasto zgoščenimi stebli, kratko koreniko in kratkimi živicami. Klaski \pm zgoščeni $\mathrm{v}$ glavičastih (kroglastih) delnih socvetjih. Krovne pleve širše, jajčaste do jajčasto suličaste, rumenozelene do rumenkastorjave (rjaste). Plodovi približno 1,5-krat daljši kot široki; prašnik 1 9. C. eragrostis
9. C. eragrostis L. [C. vegetus Willd.] - kosmatkasta o. Vlažni, peščeni bregovi voda, obcestni jarki in vlažna tla na ruderalnih mestih, subspontano. SM (Goriška Brda - Podsabotin, Istra). VII-X. Trajnica, Ge.

\section{ACKNOWLEDGEMENTS}

We are indebted to Mrs. Lidija Škaper (Podsabotin 49) for the information she provided on the occurrence of Cyperus eragrostis in the vicinity of her home and for letting us record these localities. Prof. Dr. Fabrizio Martini and Dr. Antun Alegro improved the text with valuable corrections. Andreja Šalamon Verbič translated the article into English. The research was conducted within the framework of the Biodiversity of Posočje and Nature Conservation Applications for Natura 2000 sites project, financed by the Slovenian Research Agency and Slovenian Academy of Sciences and Arts.

\section{REFERENCES}

Aeschimann, D., Lauber, K., Moser, D. M. \& Theurillat, J.-P. 2004 a: Flora alpina. Bd. 1: Lycopodiaceae-Apiaceae. Haupt Verlag, Bern, Stuttgart, Wien, 1159 pp.

Aeschimann, D., Lauber, K., Moser, D. M. \& Theurillat, J.-P. 2004 b: Flora alpina. Bd. 2: Gentianaceae-Orchidaceae. Haupt Verlag, Bern, Stuttgart, Wien, 1188 pp.

Aeschimann, D., Lauber, K., Moser, D. M. \& Theurillat, J.-P. 2004 c: Flora alpina. Bd. 3: Register. Haupt Verlag, Bern, Stuttgart, Wien, 322 pp.

Braun-Blanquet, J. 1964: Pflanzensoziologie. Grundzüge der Vegetationskunde. 3. Auflage. Springer,. Wien - New York, 865 pp.

DeFilipps, R. A. 1980: Cyperus L. In: Tutin, T. G. \& al.: Flora Europaea. Vol. 5, Cambridge University Press, Cambridge, pp. 284-288.

Ehrendorfer, F. \& Hamann, U. 1965: Vorschläge $\mathrm{zu}$ einer floristischen Kartierung von Mitteleuropa. Ber. Deutsch. Bot. Ges. 78: 35-50.

Fischer M. A., Adler, W. \& Oswald, K. 2008: Exkursionsflora von Österreich, Liechtenstein und Südtirol. Land Oberösterreich, Biologiezentrum der OÖ Landesmuseen, Linz, 1391 pp.

Jalas, J. \& Suominen, J. 1967: Mapping the distribution of Europaean vascular plants. Memoranda Soc. pro Fauna Flora Fennica 43: 60-72. 
Lauber, K. \& Wagner, G. 1998: Flora Helvetica. 2. Aufl. Verlag Haupt, Bern - Stuttgart - Wien, $1614 \mathrm{pp}$.

Martinčič, A. 2007: Cyperaceae - lisičjakovke. In: Martinčič, A. (ed.): Mala flora Slovenije. Ključ za določanje praprotnic in semenk. Tehniška založba Slovenije, Ljubljana, pp. 793-821.

Martinčič, A., Wraber, T., Jogan, N., Podobnik, A., Turk, B., Vreš, B., Ravnik, V., Frajman, B., Strgulc Krajšek, S., Trčak, B., Bačič, T., Fischer, M. A., Eler, K. \& Surina, B. 2007: Mala flora Slovenije. Ključ za določanje praprotnic in semenk. Četrta, dopolnjena in spremenjena izdaja. Tehniška založba Slovenije, Ljubljana, 967 pp.

Mekinda - Majaron, T. 1995: Klimatografija Slovenije. Temperatura zraka 1961-1990. Hidrometeorološki zavod Republike Slovenije, Ljubljana, 356 pp.

Mucina, L., Grabherr, G. \& Ellmauer, T. (eds.) 1993: Die Pflanzengesellschaften Österreichs. Teil I. Anthropogene Vegetation. Gustav Fischer Verlag, Jena, 578 pp.

Ogrin, D. 1996: Podnebni tipi v Sloveniji. Geografski vestnik (Ljubljana) 68: 39-56.

Pignatti, S. 1982: Flora d'Italia. Vol. 3. Edagricole, Roma, 780 pp.

Podani, J., 2001: SYN-TAX 2000. Computer Programs for Data Analysis in Ecology and Systematics. User's Manual, Budapest, 53 pp.

Poldini, L. (with collaboration of G. Oriolo \& M. Vidali) 2002: Nuovo Atlante corologico delle piante vascolari nel Friuli Venezia Giulia. Regione Autonoma Friuli Venezia Giulia, Azienda Parchi e Foreste Regionali \& Università degli Studi di Trieste, Dipartimento di Biologia, Udine, 529 pp.
Poldini, L., Oriolo, G. \& Vidali, M. 2001: Vascular flora of Friuli Venezia Giulia. An annotated catalogue and synonimic index. La flora vascolare del Friuli Venezia Giulia. Catalogo annotato ed indice sinonimico. Studia Geobotanica (Trieste) 21: 3-227.

Richardson, D. M., Pyšek, P., Rejmánek, M., Barbour, M. G., Panetta, F. D. \& West, C. J. 2000: Naturalization and invasion of alien plants: concepts and definitions. Diversity and Distributions 6: 93-107.

Schultze-Motel, W. 1980: Ordnung Cyperales. In: Hegi, G.: Illustrierte Flora von Mitteleuropa. Bd. II, Teil 1. Verlag Paul Parey, Berlin \& Hamburg, pp. 2-274.

Seliškar, T., Vreš, B. \& Seliškar, A. 2003: FloVegSi 2.0. Računalniški program za urejanje in analizo bioloških podatkov. Biološki inštitut ZRC SAZU, Ljubljana.

Starmühler, W. 2005: Vorarbeiten zu einer "Flora von Istrien". Teil VIII. Carinthia II 195/115 (2): 515-654.

Starmühler, W. 2006: Vorarbeiten zu einer "Flora von Istrien". Teil IX. Carinthia II 196/116 (2): 519-610.

Starmühler, W. 2008: Vorarbeiten zu einer "Flora von Istrien". Teil XI. Carinthia II 198/118 (2): 543-618.

Urbančič, M., Simončič, P., Prus, T. \& Kutnar, L. 2005: Atlas gozdnih tal. Zveza gozdarskih društev Slovenije, Gozdarski vestnik \& Gozdarski inštitut Slovenije, Ljubljana, 100 pp.

Zupančič, B. 1995: Klimatografija Slovenije. Padavine 1961-1990. Hidrometeorološki zavod Republike Slovenije, Ljubljana, 366 pp. 
Table 1: Stands with Cyperus eragrostis in Podsabotin and near the Pevmica.

Tabela 1: Sestoji z vrsto Cyperus eragrostis v Podsabotinu in ob Pevmici.

\begin{tabular}{|c|c|c|c|c|c|c|c|c|c|}
\hline & Number of relevé (Zaporedna številka popisa) & & 1 & 2 & 3 & 4 & 5 & & \\
\hline & Working number of relevé (Delovna štev. popis & & 220708 & 220710 & 219708 & 220712 & 220696 & & \\
\hline & Altitude in m (Nadmorska višina v m) & & 85 & 88 & 90 & 90 & 90 & & \\
\hline & Aspect (Lega) & & SW & 0 & 0 & 0 & 0 & & \\
\hline & Slope in degrees (Nagib v stopinjah) & & 2 & 0 & 0 & 0 & 0 & & \\
\hline & Parent material (Matična podlaga) & & Gr & $\mathrm{Gr}$ & $\mathrm{F}$ & $\mathrm{F}$ & $\mathrm{F}$ & & \\
\hline & Soil (Tla) & & $\mathrm{Fl}$ & $\mathrm{Fl}$ & Hy & Hy & Hy & & \\
\hline & Cover in \% (Zastiranje v \%): & & & & & & & & \\
\hline & Shrub layer (Grmovna plast) & E2a & 10 & 5 & . & & . & & \\
\hline & Herb layer (Zeliščna plast) & E1 & 90 & 80 & 100 & 100 & 100 & & \\
\hline & Number of species (Število vrst) & & 15 & 13 & 21 & 14 & 17 & & \\
\hline & Relevé area (Velikost popisne ploskve) & $\mathrm{m}^{2}$ & 5 & 10 & 5 & 10 & 5 & & \\
\hline & Locality (Nahajališče) & & $\begin{array}{c}\text { Pevmica } \\
\text { - SI }\end{array}$ & $\begin{array}{l}\text { Pevmica } \\
\text { - It }\end{array}$ & $\begin{array}{l}\text { Podsa- } \\
\text { botin }\end{array}$ & $\begin{array}{l}\text { Podsa- } \\
\text { botin }\end{array}$ & $\begin{array}{l}\text { Podsa- } \\
\text { botin }\end{array}$ & & \\
\hline & Date of taking relevé (Datum popisa) & & $9 / 16 / 2008$ & $9 / 16 / 2008$ & $9 / 3 / 2008$ & $9 / 16 / 2008$ & $9 / 16 / 2008$ & & \\
\hline BT & Bidentetea tripartitae & & & & & & & Pr. & \\
\hline & Cyperus eragrostis & E1 & 1 & 1 & 2 & 5 & 3 & 5 & 100 \\
\hline & Polygonum mite & E1 & . & + & 2 & . & 3 & 3 & 60 \\
\hline & Bidens frondosa & E1 & . & + & . & . & + & 2 & 40 \\
\hline & Solanum lycopersicum & E1 & . & . & . & + & . & 1 & 20 \\
\hline & Cyperus fuscus & E1 & . & . & . & + & . & 1 & 20 \\
\hline $\mathrm{FC}$ & Filipendulo-Convolvuletea & & & & & & & & \\
\hline & Rubus caesius & E1 & 2 & 2 & + & + & . & 4 & 80 \\
\hline & Calystegia sepium & E1 & . & . & 1 & . & + & 2 & 40 \\
\hline & Epilobium hirsutum & E1 & 1 & . & . & . & . & 1 & 20 \\
\hline & Lythrum salicaria & E1 & + & . & . & . & . & 1 & 20 \\
\hline & Helianthus tuberosus & E1 & . & . & . & . & + & 1 & 20 \\
\hline & Mentha longifolia & E1 & . & . & . & . & + & 1 & 20 \\
\hline PP & Potentillo-Polygonetalia & & & & & & & & \\
\hline & Agrostis stolonifera & E1 & 4 & + & . & . & + & 3 & 60 \\
\hline & Juncus inflexus & E1 & + & . & . & . & + & 2 & 40 \\
\hline & Carex hirta & E1 & . & . & 1 & . & 2 & 2 & 40 \\
\hline & Ranunculus repens & E1 & . & . & + & . & . & 1 & 20 \\
\hline & Verbena officinalis & E1 & . & . & + & . & . & 1 & 20 \\
\hline MA & Molinio-Arrhenatheretea & & & & & & & & \\
\hline & Potentilla reptans & E1 & . & . & + & + & 4 & 3 & 60 \\
\hline & Taraxacum officinale & E1 & . & . & + & + & . & 2 & 40 \\
\hline & Centaurea carniolica & E1 & . & . & + & . & . & 1 & 20 \\
\hline & Daucus carota & E1 & . & . & + & . & . & 1 & 20 \\
\hline & Juncus effusus & E1 & + & . & . & . & . & 1 & 20 \\
\hline & Scirpus sylvaticus & E1 & + & . & . & . & . & 1 & 20 \\
\hline & Trifolium pratense & E1 & . & . & + & . & . & 1 & 20 \\
\hline & Trifolium repens & E1 & . & . & . & + & . & 1 & 20 \\
\hline & Festuca pratensis & E1 & . & . & . & . & + & 1 & 20 \\
\hline SM & Stellarietea mediae & & & & & & & & \\
\hline & Echinochloa crus-galli & E1 & + & 2 & 2 & 1 & . & 4 & 80 \\
\hline & Setaria pumila & E1 & . & 2 & 3 & + & . & 3 & 60 \\
\hline & Poa annua & E1 & 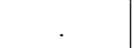 & 1 & . & + & . & 2 & 40 \\
\hline
\end{tabular}




\begin{tabular}{|c|c|c|c|c|c|c|c|c|c|}
\hline & Number of relevé (Zaporedna številka popisa) & & 1 & 2 & 3 & 4 & 5 & Pr. & Fr. \\
\hline & Stellaria media & E1 & . & + & . & . & . & 1 & 20 \\
\hline & Chenopodium album & E1 & . & . & + & . & . & 1 & 20 \\
\hline & Polygonum aviculare agg. & E1 & . & . & + & . & . & 1 & 20 \\
\hline & Polygonum persicaria & E1 & . & . & . & + & . & 1 & 20 \\
\hline \multirow[t]{4}{*}{ GU } & Galio-Urticetea & & & & & & & & \\
\hline & Urtica dioica & E1 & . & . & 1 & + & + & 3 & 60 \\
\hline & Petasites hybridus & E1 & . & 1 & . & . & . & 1 & 20 \\
\hline & Glechoma hederacea & E1 & . & . & . & . & + & 1 & 20 \\
\hline \multirow[t]{6}{*}{ AV } & Artemisietea vulgaris & & & & & & & & \\
\hline & Cichorium intybus & E1 & . & . & + & . & . & 1 & 20 \\
\hline & Picris hieracioides & E1 & . & . & + & . & . & 1 & 20 \\
\hline & Rumex obtusifolius & E1 & . & . & . & + & . & 1 & 20 \\
\hline & Melissa officinalis & E1 & . & . & . & . & + & 1 & 20 \\
\hline & Dipsacus fullonum & E1 & . & . & . & . & + & 1 & 20 \\
\hline \multirow[t]{3}{*}{ AR } & Agropiretea intermedii-repentis & & & & & & & & \\
\hline & Equisetum arvense & E1 & . & + & . & + & . & 2 & 40 \\
\hline & Elytrigia repens & E1 & . & . & + & . & . & 1 & 20 \\
\hline \multirow[t]{4}{*}{ QF } & Querco-Fagetea & & & & & & & & \\
\hline & Brachypodium sylvaticum & E1 & + & 1 & . & . & . & 2 & 40 \\
\hline & Carpinus betulus & E2a & $\mathrm{r}$ & . & . & . & . & 1 & 20 \\
\hline & Corylus avellana & E2a & $\mathrm{r}$ & . & . & . & . & 1 & 20 \\
\hline \multirow[t]{3}{*}{ RP } & Rhamno-Prunetea & & & & & & & & \\
\hline & Ligustrum vulgare & E2a & $\mathrm{r}$ & . & . & . & . & 1 & 20 \\
\hline & Cornus sanguinea & E2a & . & + & . & . & . & 1 & 20 \\
\hline \multirow[t]{4}{*}{ SP } & Salicetea purpureae, Alnetea glutinosae & & & & & & & & \\
\hline & Alnus glutinosa & E2a & + & . & . & . & . & 1 & 20 \\
\hline & Salix alba & E2a & . & . & . & . & + & 1 & 20 \\
\hline & Salix triandra & E2a & . & . & . & . & + & 1 & 20 \\
\hline \multirow[t]{3}{*}{$\mathrm{O}$} & Other species (Druge vrste) & & & & & & & & \\
\hline & Robinia pseudacacia & E2a & 1 & . & . & . & . & 1 & 20 \\
\hline & Carex spicata & E1 & . & . & + & . & . & 1 & 20 \\
\hline
\end{tabular}

